\title{
Industrial Organization and the Gains from Europe 1992
}

EUROPE 1992 promises substantial economic gains to the 12 nations that are to make up the single integrated market. From the larger market are to flow the microeconomic benefits of economies of scale and increased competition. It is these gains that are the promise of Europe 1992; the gains from macroeconomic policy come largely from capitalizing on the supply-side shock of lower prices and costs.

A quantitative estimate of the gains was made in a widely publicized report, sponsored by the Commission of the European Communities, known as the Cecchini report. ${ }^{1}$ The report estimates the microeconomic gains to be 4.3 percent to 6.4 percent of gross domestic product, with appropriate accompanying macroeconomic policies adding another 2.5 percent. ${ }^{2}$ It is a one-time gain analogous to those achieved by eliminating a domestic monopoly or a tariff. Lest the estimated gain seem small, it is several times the estimated gain of 1 percent of GDP from the 1968 elimination of tariffs on industrial products among the then-Common Market members. ${ }^{3}$ To state the relative size of the gains in another way, the midpoint of the report's estimates of the microeconomic welfare gains from Europe 1992 is 216 billion European currency units (ECU),

Susan Parker and Kyle Smith served as research assistants, and Diane Bowman typed the text. The author is much indebted to these three for their help. Research support was provided by the Mellon-West European Project at Yale University. William Parker, director of the project, provided encouragement and advice.

1. Emerson (1988). The report was prepared under the supervision of Paolo Cecchini and is widely known by his name.

2. Ibid., p. 167 and p. 19.

3. Swann $(1984$, p. 118). 
or $\$ 263$ billion-about $\$ 810$ for every man, woman, and child in the Community. ${ }^{4}$

The first part of this paper examines how the report arrives at its estimates. The microeconomic task was formidable-a prediction of the difference between the prices and costs expected in the single Community market and those expected from continuation of the status quo. The effort and care applied to the task is impressive; many of the leading European economists and consulting firms were enlisted in the research, and the results occupy some 15 volumes. Paolo Cecchini observes that the research was unprecedented "for the sheer size of its scope, but also because of the novelty of the subject matter and the methodological difficulties . . based on it. A further problem was the unevenness of the empirical data on European market fragmentation. Yet despite the fragilities, the results that emerge tell an unmistakable story." ${ }_{5}$

That a single European market will raise real incomes is a "story" that few economists would dispute. Yet I believe that the details of the story are more questionable, that certain economic assumptions, limitations, and omissions make the report's estimates of the gains optimistic. It is important to emphasize this overoptimism, given the significance of the report both as a work of economic advocacy and as an impressive scientific study.

A second problem in the report is its bold political assumption that all 12 nations of the Community will cooperate with the removal of all the barriers to a single integrated Community market. Removing these barriers represents the classic problem of political economy. The Community as a whole is a gainer, but well-organized groups in each nation will be losers and can be expected to resist the efforts to create Community gains at their expense. The second section examines this critical problem.

The last part of the paper examines the impact of Europe 1992 on American firms operating in Europe. It also looks briefly at the question of the regulation of mergers by the Community.

4. Cecchini (1988, p. 107). The dollar amount is based on an exchange rate of 1.00 ECU to $\$ 1.22$, the mid-March 1988 rate. The per capita calculations are by the author. These estimates are in 1988 prices.

5. Emerson (1988, p. xviii). 
Table 1. Estimates of Total Welfare Gains for Seven European Countries from Completing the Internal Market under Two Sets of Assumptions ${ }^{\mathrm{a}}$

Percent of GDP

\begin{tabular}{lrr}
\hline \multicolumn{1}{c}{ Item } & \multicolumn{2}{c}{ Estimate $^{\mathrm{b}}$} \\
\cline { 2 - 3 } & $A$ & $B$ \\
\hline Direct gains from elimination of barriers & & \\
Stage 1: barriers affecting trade only & 0.2 & 0.3 \\
Stage 2: other barriers affecting production & 2.0 & 2.4 \\
$\quad$ Subtotal & 2.2 & 2.7 \\
Indirect gains from market integration & & \\
Stage 3: economies of scale from restructuring and increased production & 2.0 & 2.1 \\
Stage 4: competition effects on X-inefficiency & 1.6 & 1.6 \\
Subtotalc & 3.6 & 3.7 \\
$\quad$ Variant I (sum of stages 3 and 4 above) & 2.1 & 2.1 \\
$\quad$ Variant II (stages 3 and 4 computed jointly) & & \\
Total gains & 5.8 & 6.4 \\
$\quad$ Variant I & 4.3 & 4.8 \\
Variant II & & \\
\hline
\end{tabular}

Source: Emerson (1988, table 10.1.1).

a. Estimates based on 1985 data at 1985 prices.

b. The A and B estimates reflect differing data sources or assumptions introduced in stages 1 and 2 . At stage 1 , the A estimates are based on a study of the cost of border barriers by a consulting firm, and the B estimates are based on costs from a 3,000-firm survey. At stage 2, the A estimates assume no reduction in prices for steel and agricultural products, and B estimates assume prices in both sectors decline 5 percent. These two sectors are special cases since the Community, through the European Iron and Steel Commission and the Common Agricultural Policy, sets prices and outputs.

c. For explanations of variants I and II, see the text.

\section{The Gains from 1992}

Table 1 lays out the estimates in the Cecchini report of the microeconomic gains from creating the Community market. The estimates are for seven European countries (Germany, France, Italy, the United Kingdom, Belgium, the Netherlands, and Luxembourg) that account for 88 percent of total Community GDP. ${ }^{6}$ Data were available for these seven; the assumption was that the remaining five countries in the Community would realize gains of the same percentage of their GDPs.

The gains in table 1 do not assume enactment of what the report calls the appropriate accompanying macroeconomic policy, though one implicit assumption is full employment-that resources released by cost

6. Ibid, p. 201. 
reductions will be employed elsewhere in the economy. The estimates are partial equilibrium ones in the sense that they "add up estimates made independently for many individual sectors, and do not work through the 'general equilibrium' results that would take into account changes in relative prices." 7 The results from a general equilibrium model are said to differ insignificantly, and time and data constraints are said to have precluded the general equilibrium approach.

The objective is to measure welfare gains-the increase in consumer surplus less the loss in producer surplus. In the calculations, however, price reductions are often assumed to match cost reductions, leaving the producer surplus per unit unchanged. Agriculture, financial services, and coal are exceptions. For example, three-fifths of the price reduction in agriculture is considered a reduction in rents; the remainder, a net welfare gain. ${ }^{8}$

The starting point for table 1 is the estimate made by Richard Cawley and Michael Davenport, who use partial equilibrium analysis to calculate the direct welfare gains from creating the Community market for each sector (stages 1 and 2). The larger indirect gains that result from greater economies of scale and increased competition (stages 3 and 4) are not directly estimated. Instead, the estimates are derived from the simulation of the Alasdair Smith and Anthony Venables model of trade in imperfectly competitive markets. The particular sectoral calculations of Smith and Venables are then generalized to derive coefficients with which to estimate the indirect gains as a multiple of the direct gains in each sector, as estimated by Cawley and Davenport. ${ }^{9}$

\section{Estimates of Direct Gains}

To estimate the direct gains, Cawley and Davenport quantify the economic costs of existing barriers, including border formalities, national diversity of product standards, or, more generally, nontariff barriers that create a wedge between the price of domestic goods and delivered exports. ${ }^{10}$ The Cawley and Davenport model for stage 1 uses a three-

7. Ibid., p. 202.

8. Ibid., pp. 232-34.

9. Ibid., pp. 234, 242-45.

10. Cawley and Davenport (1988, p. 93). 
country framework with a single Community country importing from the rest of the Community and the rest of the world. The welfare gains to the Community from 1992 for each sector are totaled by calculating, for each of seven Community countries, the gains to the single country and the gains to the rest of the Community from removal of trade barriers on final demand goods. ${ }^{11}$

The estimate for the electrical machinery sector illustrates the procedure. From a consultant's study, the reduction in costs with a single European market is estimated to be 1.4 percent of the current costs of production. This procedure results in a price reduction of 0.7 percentreflecting the impact of price elasticities along with cost reductions. With the lower price in the Community, imports from the rest of the world decline by 0.6 percent. All the percentages are weighted averages for seven member states.

The welfare gain is estimated by the standard partial equilibrium technique as the sum of the changes in producer and consumer surplus. The gain depends on the percentage cost reduction, the export elasticity of supply for the rest of the world, and the import elasticity of demand for the Community. In the case of electrical machinery, the welfare gain is 100 million ECU.

Stage 2 estimates are derived in the same general way, except that the Community is treated as one economic unit. The important aspect of stage 2 is that the effect of price reductions in intermediate goods on the price of final demand goods is estimated by use of an input-output matrix. ${ }^{12}$

Cawley and Davenport acknowledge that their analysis assumes perfectly competitive markets and omits the costs of adjustment, as well as the time required to achieve the new equilibrium. The data required to estimate their model include trade and production volumes, import and export elasticities, and estimates of potential cost reductions. Estimates of cost reductions are taken from firm surveys and particular sectoral studies done for their project. ${ }^{13}$ The elasticities are taken from previous work and extrapolated for sectors in which there are no published elasticities.

11. Ibid., pp. 498-99.

12. Ibid., pp. 502-06.

13. Ibid., pp. 495, 509-13, 529-31. 


\section{Estimates of Indirect Gains}

Indirect gains (stages 3 and 4 of the estimates) come from the realization of economies of scale, from the restructuring of industry, and from the elimination of X-inefficiencies by the pressure of more competitive markets. (X-inefficiencies, or, more popularly, corporate slack, arise because competitive pressures are weak and firms can operate below their production frontiers.)

A simple example illustrates what is to happen. Assume three firms exist, each a monopolist in its national market. Now the three national markets become one community market. Two firms survive, each selling in all three national markets and each with a higher volume. The higher volume allows each to realize economies of scale. Lower costs, in turn, are assumed to result in lower prices, thus providing one source of the welfare gains. The two remaining firms are now in direct competition with one another. Concentration has declined and the surviving firms, under greater competitive pressure, reduce their corporate slack-thus further reducing their costs and prices. This is the second source of welfare gains. The larger market then provides both a greater realization of economies of scale and increased competition.

As table 1 indicates, there are two estimates of indirect gains, variants I and II, although both rely on the Smith and Venables model. Variant I computes separately the gains from economies of scale and the gains from the elimination of corporate slack; variant II computes the two gains jointly, relying solely on the coefficients derived from the Smith and Venables model. ${ }^{14}$

The welfare calculations used in the report assume Cournot behavior by oligopolists (each firm sets its output while taking other firms' outputs as given)and integrated markets, in which firms have no ability to pricediscriminate among national markets. ${ }^{15}$ Smith and Venables also provide the results from employing other assumptions, including Bertrand behavior (each firm sets its price while taking other firms' prices as given) and segmented markets, in which firms retain some ability to charge higher prices in their national markets, because consumers have some preference for products traditionally sold in their markets.

14. Emerson (1988, pp. 240-43).

15. Ibid., pp. 242-43. 
Smith and Venables divide the world into six "countries," France, Germany, Italy, the United Kingdom, the "rest of the EC," and the "rest of the world." For 10 industries, they estimate the welfare gains from the comparative statics of a transition from six national markets to a united European market. As noted in the example, the single market reduces industry concentration faced by each member country and thus, it is assumed, increases competition to eliminate $\mathrm{X}$-inefficiency. The larger market also allows greater economies of scale.

Data required by the model include trade flows among countries, domestic production statistics, the Herfindahl index by sector for each country, measures of economies of scale, and elasticities of demand for each sector. Necessary data are often not available, requiring the authors to substitute arbitrary estimates. For example, production data for the "rest of the world" are chosen so that the ratio of production to exports to the EC is the same as that for the average of the four individual EC countries. Estimates of the Herfindahl index for industries in each country involve similar arbitrary assignments. ${ }^{16}$

Variant II, the easier to describe, uses the results from the Smith and Venables model to calculate the ratio of indirect to direct gains (as calculated by Cawley and Davenport) for 10 industries. The ratio depends on how much the shift from a national to a Community market reduces the concentration faced by each country and hence increases competition and how much that shift permits the realization of greater economies of scale.

In some industries there are no indirect gains, for national markets are already so fragmented that there are no gains from increased competition and no unrealized economies of scale. Thus agriculture has a zero ratio or coefficient: that is, there will be no indirect gains, given its already fragmented market structure. Textiles have/a ratio of 1.0: that is, indirect and direct gains are equal and the shift to a Community market will lead to a reduction in its concentration that will result in somewhat greater competition and economies of scale. Motor vehicles, now highly concentrated in national markets, have a ratio of 6.0: that is, indirect gains are six times the direct gains because the shift to a Community market will significantly lower concentration and permit the realization of substantial economies of scale. Large indirect gains occur in industries that are now highly concentrated in their national markets.

16. Smith and Venables (1988, pp. 294-97). 
Competition (the greatest source of indirect gains) is assumed to be determined by market concentration, the share held by the largest firms.

This procedure gives the variant II estimates shown for stage 3 and stage 4 in table $1 .{ }^{17}$ Since Smith and Venables perform calculations only for 4 countries and 10 industries, estimated ratios or coefficients are derived for other industries and the rest of the Community by prodigious extrapolations. ${ }^{18}$

Variant I separates gains from economies of scale and gains due to increased competition. The latter are again computed from the Smith and Venables model using the procedures described for variant II, but only to compute the effect of the reduction in concentration and resulting increased competition. The estimates of the gains from realization of economies of scale are based on models by Joachim Schwalbach and by Rodolfo Heig and Pippo Ranci that focus on the current gap between plant size and minimum efficient technical scale (METS), as estimated, in turn, in a study by Cliff Pratten. The calculations of gains based on these studies are done by Michael Aujean. ${ }^{19} \mathrm{He}$ assumes Community trade increases by 25 percent with an integrated market. The larger market, in turn, is assumed to reduce the gap between plant size and METS, leading to cost reductions. The cost reductions vary among industries, depending on the magnitude of the current gap and the size of the costs of a shortfall from optimal scale. The cost reductions, in turn, are converted to the welfare gains using partial equilibrium analysis. ${ }^{20}$

The simulations for both variants assume that economies of scale will be realized and that the number of firms will adjust to numbers required for the lowest-cost production. By assumption, markets will be in equilibrium, yet real markets, even the most competitive, are frequently in disequilibrium. Competition is assumed to be determined by concentration, though most empirical studies do not show a close relationship between concentration and competition. The time required to reach the new equilibrium is not specified, though, elsewhere in the report, 10 years is mentioned as a probable length of time required to achieve many of

17. Emerson (1988, p. 243).

18. Ibid.

19. Aujean (1988, pp. 549-57). The same volume contains Schwalbach (1988); Heig and Ranci (1988); and Pratten (1988).

20. Emerson (1988, pp. 242-44). 
the gains. ${ }^{21}$ The time path and the costs of transition are nowhere discussed.

\section{Gains in Key Sectors}

There are so many details and assumptions within the estimates that a full examination of the models and their simulations would require an exposition as long as the report itself. Instead, I will focus on the plausibility of the results.

The report divides the European economy into 36 sectors, 7 of which, as table 2 shows, account for about 60 percent of the total gains. Within these sectors, most of the gains arise in stages 3 and 4 . For example, in motor vehicles as much as 87 percent of the gains comes in these two stages-that is, from the reorganization of the industry to capitalize on economies of scale and from increased competition. Some of the estimated gains are extraordinary; in motor vehicles and other transport, the gains are 18.7 percent to 25.1 percent of the GDP originating in that sector. ${ }^{22}$

\section{Alternative Estimates of Gains in the Automobile Industry}

A disturbing aspect of the simulations is that different but still reasonable assumptions generate widely varying welfare gains. A comparison of the gains in the automobile industry for four of eight different permutations of the Smith and Venables model illustrates the point.

In each of the four estimates, the number of automobile models is assumed constant, and the number of firms is assumed variable. A major difference among the estimates comes from whether markets are assumed to be segmented or integrated. The segmented market may be the more realistic assumption, for it recognizes that firms will retain their market positions in their national markets even after 1992. Mercedes, for example, would continue to be preferred by German consumers more than by Italian consumers. With the integrated market assumption, consumers would be uninfluenced by their past consumption, and preferences between Mercedes and Fiat would be similar for both German and Italian consumers.

21. Ibid., p. 201.

22. Ibid., tables A.8 and C.2. 
Table 2. Welfare Gains in Key Sectors ${ }^{\mathrm{a}}$

Billions of ECU except as noted

\begin{tabular}{lcccc}
\hline \multicolumn{1}{c}{ Sector } & $\begin{array}{c}\text { Projected } \\
\text { gains }\end{array}$ & $\begin{array}{c}\text { Sector } \\
\text { GDP }\end{array}$ & $\begin{array}{c}\text { Gains as } \\
\text { percent of } \\
\text { sector GDP }\end{array}$ & $\begin{array}{c}\text { Gains as percent } \\
\text { of total gains }\end{array}$ \\
\hline Motor vehicles and other & & & & \\
$\quad$ transport & $17.8-23.9$ & 95.2 & $18.7-25.1$ & $14.0-12.8$ \\
Electrical goods & $15.7-19.7$ & 85.3 & $18.4-23.1$ & $12.4-10.5$ \\
Mechanical engineering & $11.3-14.0$ & $82.3^{\mathrm{c}}$ & $13.7-17.0$ & $8.9-7.5$ \\
Food, edibles, and tobacco & $8.7-18.2$ & 136.7 & $6.4-13.3$ & $6.9-9.7$ \\
Credit and insurance & $10.5-11.7$ & 264.5 & $4.0-4.4$ & $8.3-6.3$ \\
Chemicals & $9.2-15.2$ & 80.3 & $11.5-18.9$ & $7.3-8.1$ \\
Office machinery & $6.6-6.9$ & 28.2 & $23.4-24.4$ & $5.2-3.7$ \\
Total & $79.9-109.6$ & 772.5 & $10.3-14.1$ & $63.1-58.6$ \\
\hline
\end{tabular}

Source: Projected sector and total gains from Emerson (1988, table A.8). Sector GDP from table C.2.

a. Components may not sum to totals because of rounding.

b. Highest estimate of the total gains is 187.0 billion ECU. Lowest estimate is 126.3 billion ECU.

c. Sector GDP is that of agricultural and industrial machinery.

Another major difference is the choice of Cournot or Bertrand models of oligopoly. In the Bertrand model a few rivals already provide significant competition. Thus the shift to the lesser concentration each country would face in a Community market does not provide as much of a change in price as it does in the Cournot model. Of the two, the Cournot model is the better description of reality; yet oligopoly produces a wide range of outcomes of which the Cournot solution is only one.

The wide range of estimates is unsettling, as is the selection of the highest welfare gains for the final report estimates. The chosen estimate of 12.0 billion ECU for the variant using Cournot behavior and integrated markets dwarfs the welfare gains estimated with other versions of the model. Estimated gains for the Cournot behavior, segmented markets variant are 1.33 billion ECU; gains for the Bertrand behavior, integrated markets variant are 0.89 billion ECU; and gains for the Bertrand behavior, segregated markets variant are 0.88 billion ECU. ${ }^{23}$ Clearly, the analysis does not pass a sensitivity test.

The results of the Smith and Venables model can also be compared with the case study of the EC 92 Automobile Sector undertaken for the project by Ludvigsen Associates. ${ }^{24}$ This study estimates a cost savings of 2.6 billion ECU with a single market, a reduction of 5 percent in total

23. Change in welfare as percent of consumption from Smith and Venables (1988, table 6). Percent converted to billion ECU from Emerson (1988, table A.8).

24. Ludvigsen Associates Ltd. (1988, annex 1). 
costs. Even to derive this estimate, which is conservative in comparison with the 12.0 billion ECU used in the report, requires assumptions of complete realization of economies of scale, as determined by engineering analysts, that will arise through full cooperation among the European automobile manufacturers in sharing components and parts. The gains in the Ludvigsen study arise mainly through production economies of scale from "more extensive transborder interpenetration of parts, components, assemblies, and built-up vehicles." The study projects that the number of different designs by which platforms, or basic car chassis, are manufactured in the Community will be reduced from 30 to 21 by the sharing of platform designs by different manufacturers. Most of the realized gains from 1992 in this study are contingent upon achieving a reduction in platform designs, and volume per platform design must increase an average of 50 percent to realize these economies. ${ }^{25}$ Thus, the study implicitly assumes that firms are willing to cooperate with each other and to eliminate the "unnecessary" platform designs. The analysis does not consider costs of adjustment and reorganization.

The Ludvigsen study also raises the question of the appropriate price elasticity of demand to use for the automobile sector. The elasticity used in the Ludvigsen study is $1.2,{ }^{26}$ while that used to estimate the Smith and Venables model is 1.63. (The elasticity of demand for each differentiated product used to calibrate the Cournot version of the Smith and Venables model, derived from first-order conditions for profit maximization, is 13.32. $)^{27}$ The higher the elasticity, of course, the greater the welfare gains.

The approach adopted in the report assumes that the welfare gains flow to the consumers in the Community. The distribution of the gains among nations is not specified. Wages are assumed to be unchanged. The gains come from the elimination of X-inefficiency and of inefficient firms. Both the considerable reorganization that is assumed to occur and the effect on wages of increased competition are discussed subsequently.

\section{Alternative Sectoral Estimates}

Still another way of evaluating the results of the simulations is to compare them with alternative ways of estimating the gains. Table 3

25. Ludvigsen Associates Ltd. (1988, pp. 383, 388, 395).

26. Ibid., p. 393.

27. Smith and Venables (1988, p. 317). 
Table 3. Alternative Estimates of Gains in Selected Sectors

Billions of ECU

\begin{tabular}{lcccc}
\hline \multicolumn{1}{c}{ Sector } & $\begin{array}{c}\text { Barrier } \\
\text { removal and } \\
\text { integration }\end{array}$ & $\begin{array}{c}\text { Sectoral } \\
\text { studies }\end{array}$ & $\begin{array}{c}\text { Business } \\
\text { surveys }\end{array}$ & $\begin{array}{c}\text { Price } \\
\text { convergence }\end{array}$ \\
\hline Agriculture & $0.7-4.2$ & $\ldots$ & $\ldots$ & 0.0 \\
Ores, metals & $0.5-4.6$ & $\ldots$ & $\ldots$ & 0.0 \\
Nonmetallic minerals & $1.0-2.6$ & $\ldots$ & 1.4 & 3.3 \\
Chemicals & $9.2-15.2$ & $\ldots$ & 1.3 & 9.2 \\
Metal articles & $2.0-5.2$ & $\ldots$ & 1.6 & 1.5 \\
Mechanical engineering & $11.3-14.0$ & $\ldots$ & 2.0 & 8.1 \\
Office machinery & $6.6-6.9$ & $\ldots$ & $2.3^{\mathrm{b}}$ & 2.6 \\
Electrical goods & $15.7-19.7$ & $\ldots$ & $2.1^{\mathrm{c}}$ & 5.6 \\
Motor vehicles & $14.1-17.8$ & 2.6 & $2.2^{\mathrm{d}}$ & 7.7 \\
Other transport & $3.7-6.1$ & $\ldots$ & 1.3 & 2.1 \\
Edibles and tobacco & $8.7-18.2$ & $0.5-1.0^{\mathrm{e}}$ & 2.3 & 14.1 \\
Textiles, leather, clothing & $4.4-4.7$ & $0.7-1.3$ & 4.0 & 5.9 \\
Timber, furniture & $1.4-1.6$ & $\ldots$ & 1.5 & 1.1 \\
Paper products & $2.7-5.0$ & $\ldots$. & $1.5^{\mathrm{f}}$ & 0.9 \\
Building, civil engineering & $4.3-7.2$ & 2.8 & $\ldots$ & 19.2 \\
Financial services (credit, & & & & \\
$\quad$ insurance) & $10.5-11.7$ & 22.0 & $\ldots$ & 7.0 \\
Inland transport & $1.5-1.9$ & $5.0^{\mathrm{g}}$ & $\ldots$ & 0.0 \\
Communication services & $1.7-1.8$ & 6.0 & $\ldots$ & 10.2 \\
Total ${ }^{\mathrm{h}}$ & 156.7 & 70.0 & 50.2 & 112.0 \\
Total as percent of GDP & 5.4 & 2.4 & 1.7 & 3.9 \\
\hline
\end{tabular}

Source: Barrier removal and integration figures from Emerson (1988, table A.8). Sectoral studies from table A.1. Business surveys from table A.2. Price convergence from table A-9, hypothesis 2. See text for explanation.

a. Numbers are midpoints of estimate ranges.

b. Includes precision equipment.

c. Gains in electrical engineering.

d. Includes parts and accessories.

e. Does not include tobacco.

f. Includes printing and publishing.

g. Road transport.

h. Total includes sectors not shown in table. Numbers are midpoints of estimate ranges.

i. Twelve countries, 1985 data. Numbers are midpoints of estimate ranges.

compares the estimate of the method used in the report with estimates by three alternative methods also mentioned in the report: gains based on studies of specific industries, findings from business surveys, and gains determined by the price-convergence method. The price-convergence method assumes goods and services will partially obey the law of one price. Current prices for manufactured goods in countries above the Community average will come down to Community average prices, and current prices for services will fall to the average of the two countries 
with the lowest prices. ${ }^{28}$ (Trade in services is regarded as more restricted than that in manufactured goods, and thus as subject to the greater price declines with a single market.)

That the method used in the report gives much higher estimates than these three alternatives do is not surprising, for the model used in the report takes account of more effects and more sectors. It does so, however, only by making heroic assumptions and extrapolations. Yet, as table 3 shows, even the more conservative alternative approaches still yield positive total gains, the lowest being 1.5 percent of GDP.

\section{The Magnitude of the Overestimate}

If the estimate in the report is overly optimistic, then by how much? To produce an alternative estimate well-grounded in theory and data would be a monumental task, but the reader may be entitled to a guess as to the order of magnitude of the overestimate. On the basis that Europe 1992 is a more comprehensive set of changes than the 1968 elimination of tariffs on industrial products mentioned at the outset, I would hazard an estimate of twice these gains-that is, the microeconomic gains would be about 2 percent of GDP. ${ }^{29} \mathrm{I}$ conclude then that the report overestimates the gains by a factor of two or three.

A 2 percent gain is within the range of those produced by the various alternative methods. This more modest number is still 66 billion ECU ( $\$ 80$ billion), a per capita gain of about $\$ 250 .^{30}$

The report emphasizes what are called dynamic gains-those from greater technological innovation, the effect of the learning curve on unit costs, and business strategies "better suited to securing a strong place in the world market competition." 31 The increased competition and larger market of Europe 1992 are said to promote such dynamic gains. No estimate is given in the report for dynamic gains, even though they are held to be important, because of the view that there is little basis for estimating their magnitude.

28. Emerson (1988, pp. 244-49).

29. My colleague Willem Buiter points out that the Central Planning Bureau of the Netherlands $(1989$, p. 538) estimated the microeconomic gains as 2.5 percent.

30. The $\$ 250$ per capita estimates are in 1985 prices and should be compared with $\$ 540$ for the report. The earlier cited amount, $\$ 810$, is in 1988 prices.

31. Emerson (1988, p. 7). 
Dynamic gains are important because they affect the annual growth rate of the Community rather than create a one-time gain. There may well be such dynamic gains, but studies have shown how difficult it is to raise significantly the long-term growth rate of an economy. ${ }^{32}$

\section{The Political Obstacles}

The task in the Cecchini report was to estimate the gains of Europe 1992 on the assumption that all the proposals for a single integrated market would be accepted by the 12 member states. It would not be a fair comment on the estimates in the report, then, to question such a bold political assumption. Yet the assumption of willing, indeed enthusiastic, cooperation of European governments needs to be examined, for the character of political cooperation of national governments is critical to what Europe 1992 can achieve with microeconomic policy.

\section{Industrial Reorganization}

A major source of the 1992 gains is a reorganization of European industry to take advantage of economies of scale, requiring that the number of plants and firms be reduced. In the simulations just described, the number of firms in the Community declines in all but two industries (cement, in which transport costs are substantial, and office machinery, in which price elasticities are high). The extreme case is footwear, in which 207 of the 739 firms in the Community are predicted to disappear. Some nations are almost sure to be losers in the reorganization. For example, in the simulations, the United Kingdom loses 46 of its 65 footwear firms, 31 of its 52 carpet firms, and 1 of its 3 motor vehicle firms. ${ }^{33}$

The history of industrial policy shows that European national governments have not passively accepted the closing of firms, but rather have devised state aids to rescue some of the losers. Indeed, Europe has a tradition of rescuing national firms in trouble, though in some industries the decline in the number of firms has been accepted, particularly for

32. See, for example, Denison (1967, p. 301).

33. Smith and Venables (1988, pp. 316-17, 319, 329-30). 
low-technology industries made up of small firms ${ }^{34}$ Still, it is state aids of various sorts that explain why Europe has 12 manufacturers of industrial boilers or 16 manufacturers of electric locomotives compared with 2 firms in each industry in the United States. ${ }^{35}$

The report assumes that future industrial policy will be different. The legal environment is to change. To restrain or forbid state subsidies, the Commission will use its existing powers, including its new power to require enterprises to repay aid ruled illegal by the Community. But inevitably the policing from Brussels will be limited, and, as the report observed, what is required is "the demonstrable willingness of Member states to accept these rules of the game, rather than conduct long political and procedural struggles over illegal subsidy regimes." 36 Whether such a change in attitude will occur is problematic, particularly since one transgressor among the 12 member nations will encourage others.

\section{Barriers from Technical Regulations}

The same question of political will arises in technical regulations that now block the creation of a single market. The report estimates that the gains to reducing these regulations are substantial-about 30 billion ECU. (These gains are counted in stages 1 and 2 of table 1.) About 100,000 technical regulations and standards will need to be changed or eliminated. Examples of actions required include the repeal of the Italian Pasta Purity law, which requires pasta to be made entirely of durum wheat, and thus effectively excludes pasta from other countries. Some of the barriers are not embodied in the laws themselves but are in standards or certification for products. For example, in France, a national standardization body sets specifications for tiles that effectively exclude Spanish and Italian products because nonconforming tiles cannot be used in public buildings and because most French architects insist on using tiles that meet national specifications. ${ }^{37}$

34. Hall (1986).

35. Emerson (1988, p. 56).

36. Ibid., pp. 7-8.

37. Emerson estimated the costs of frontier formalities, technical regulations, and other miscellaneous barriers at 40 billion ECU, of which frontier formalities alone comprise 9 billion. Emerson (1988, pp. 3, 39, 46-47). 
Technical regulations and standards are then still another device that protects national firms. The report assumes these barriers will crumble, either by the mutual recognition principle by which products lawfully marketed in one member state can be marketed in any other or by the creation of Community standards. ${ }^{38}$ The political problems are similar to those with state aid, complicated by the real and imagined consumer protection aspects of many of the existing technical regulations and standards.

\section{Public Procurement}

The preference of governments, in their own purchases, for domestic over foreign suppliers constitutes another significant barrier to the integrated market. According to the report, the opening up of public procurement to the least-cost supplier within the Community will yield 18 billion ECU in gains (counted primarily in stage 2 of table 1), concentrated in defense procurement, telecommunications equipment, pharmaceuticals, rail rolling stock, and electrical equipment. ${ }^{39}$

The numerical estimates are based on a combination of price surveys, interviews, and studies of particular sectors. They include both static welfare gains and industry restructuring gains, with the restructuring accounting for 40 percent of the total procurement gains. Since procurement is only a small part of the demand in most industries, the opening up of public procurement alone would not lead to substantial industry reorganization. In seven industries, however, ranging from turbine generators to railroad locomotives, public demand is large enough to create some restructuring. Four billion ECU of the gains are in the defense sector, primarily in weapons and missile systems. ${ }^{40}$ These savings come largely from eliminating duplicate research and development in the defense programs of the member states.

Again there are political obstacles, which stand out here since the decisions are directly those of governments. The past history is not encouraging. Since about 1970 the Community has been committed to eliminating preference for domestic firms in public purchases. Specific directives have been introduced to create common rules in the technical

38. Ibid., p. 48.

39. Ibid., p. 52; and W. S. Atkins Management Consultants (1988, pp. 107, 115).

40. Emerson (1988, pp. 52, 54). 
fields, the harmonization of award procedures, and the advertising of invitations to bid. Even so, only 2 percent of public procurement is now awarded to firms from other member states. And the report states, "the Commission has found that the Community rules are frequently broken." 41

This history is significant, not so much for public procurement alone, but as a demonstration of how difficult it is to overcome national nepotism. It does not augur well for other kinds of national preference. Again, the assumption is that 1992 is to be a break from the past. Governments are to think European, not British, French, or German.

\section{Increased Competition and Wages}

The report is silent as to the impact on wages of increased competition in the product market. The recent experience of the United States with both deregulation and greater import penetration is that increased competition in the product market can have repercussions in the labor market. The most striking change in the United States was in the trucking industry, in which the premium for union over nonunion drivers declined from 50 percent to 25 percent with deregulation and the resulting increase in competition. ${ }^{42}$ Deregulation and increased import competition also pushed wages down in such diverse industries as airlines, steel, and automobiles.

The impact on wages of a single European market could be substantial, given the wide disparity in wages between the northern and southern member states. ${ }^{43}$ Apart from direct competition between high- and lowwage firms in the product market, the U.S. experience is that some kinds of manufacturing will tend to move to the low-wage regions. Thus after World War II, the U.S. textile industry moved from New England to the South. The decision of the Ford Motor Company to locate its newest parts plant in Spain hints of similar developments in Europe. ${ }^{44}$

41. Ibid., p. 48.

42. Rose (1985).

43. The 1988 average hourly wage in manufacturing in West Germany and the three lowest-wage countries was, on an index of United States $=100$, West Germany, 130; Spain, 63; Greece, 34; and Portugal, 20. Dornbusch (1989b, table 4).

44. "Ford Cites Labor in Choice of Spain for Parts Factory," Wall Street Journal, Sept. 16, 1988, p. 22. 
One can then visualize a scenario in which the high-wage plants in northern Europe begin to close as economies of scale interact with new investment in the low-wage member countries. Such a development is most likely during a recession in which general unemployment is rising. National governments will be under great pressure to take measures to save local plants and employment. They can plead that their hands are tied, that the commitment to the Common Market gives them no freedom of action. And yet if the pressures become strong enough, surely some enterprising politicians will capitalize upon them. Such a gloomy scenario need not happen, though the risk is substantial. If the single market creates enough gains soon enough and if the gains are widely distributed by nation and industry, there will be a basis to resist such pressures.

One need not focus on such a crisis scenario to predict that lowerwage countries of the Community will gain more from Europe 1992 than the high-wage ones. The elimination of trade barriers will make lowwage countries more attractive locations for production. Higher-quality labor and a better national infrastructure that results in higher labor productivity have historically offset wage differences. Labor quality is more important, however, in some industries than others. One would expect the gradual migration of lower-skilled production to the lowwage countries of the Community. These are the industries in which imports from third world countries have been increasing, and so production in Spain, Portugal, and Greece may be substituted for such imports. Yet there are intermediate-skill cases, such as the Ford parts plant just cited, in which a country like Spain becomes a substitute for production in high-wage northern Europe. A trend toward the location of manufacturing in the Community's low-wage countries may place a strain on the political viability of 1992, unless macroeconomic policy can ensure high employment.

\section{The Impact on U.S. Firms Operating in Europe}

U.S. firms operating within Community boundaries should benefit along with Community firms from the larger market. The elimination of border formalities should mean that nations cannot single out the products of U.S. firms manufacturing in Europe from those of Community firms. Indeed, because many U.S. firms are already selling in most 
of the member states and have Europe-wide marketing and production strategies, they may be better positioned to take advantage of the single market than European firms.

Food products are an oft-cited example. Of the 10 largest food processing groups worldwide, 8 are American, with Unilever (United Kingdom) and Nestlé (Switzerland) being the exceptions. In the past 10 years there has been a worldwide consolidation in the food processing industry, with nearly 100 major acquisitions. The big 10 already operate in most of Europe. In contrast, the 46 largest European companies are largely tied to national markets, with only two, Unilever and Nestlé, operating in all four of the largest Community countries. ${ }^{45}$ Thus, most of the Community firms will need to develop marketing channels to expand outside their national market, whereas U.S. firms have already established these channels.

The German consumer may not care whether his or her soup is made by Campbell's or by a Community firm. Clearly, much of the European business community and their national governments do care; they hope Europe 1992 will help European firms, not what they regard as interlopers from the United States.

In two areas-public procurement and research support-U.S. firms may be at a disadvantage relative to Community firms. Each area involves direct national government or Community action so that the integrated market by itself does not ensure the equal treatment of U.S. firms.

Liberalization of public procurement is usually formulated in terms of access for Community firms. The definition of a Community firm is left unspecified. If it is difficult, as discussed earlier, for a national government to accept a company from a neighboring country on a parity with one of its own in its purchase decisions, it may be even more difficult to place a U.S. firm on a par with a Community firm. There is not yet enough experience to evaluate whether this will be a real or imagined problem for U.S. firms manufacturing in Europe. The best guess is that preference for Community firms will vary among countries and among products.

Community firms are likely to be given preference for Community research support. In 1987, the Community spent about 0.9 billion ECU ( $\$ 1.1$ billion) of its own budget on research and development, largely

45. Emerson (1988, pp. 70-71). 
through programs with marvelous acronyms-ESPRIT (European Strategic Program for Research in Information Technology), RACE (Research in Advanced Communications for Europe), and BRITE (Basic Research in Industrial Technologies for Europe). ${ }^{46}$ These programs typically involve the Community in providing matching grants to European companies, universities, and research institutes for basic and applied research. While the absolute amount is large, Community spending on $R \& D$ is only a small fraction of total European $R \& D$ spending, most of which is done by private firms and national governments.

The avowed objective of Community R\&D spending is to improve European competitiveness in high-technology industries relative to the United States and Japan, an objective not well served by granting research support to the European subsidiaries of U.S. firms. In fact, U.S. firms have been able to participate in these programs, but according to one author, "there is a pervasive belief among U.S. firms that these $\mathrm{R} \& D$ programs are intended for EC firms, and the Commission, while not wanting to exclude U.S. firms as a matter of principle, tries to limit their participation to areas where they can offer technology that would otherwise be unavailable." 47

While these kinds of discrimination against U.S. firms based in Europe may be important to particular firms, they are not significant for most U.S. European operations. Still, a wider range of EC policies could reflect a more basic attitude that "the single market must first offer an advantage to European companies. This is a message we must insist upon without hesitation." 48

In an age of multinational corporations, it is increasingly unclear what the nationality of such a corporation is or, indeed, whether it has any nationality at all. That may make Community preference eventually meaningless. Still, full internationalization of corporations seems a long way off, and Community preference could become a source of friction between the Community and the United States.

46. European Community Office of Press and Public Affairs (1987, pp. 9, 12). The sum cited in the text is an overestimate of research and development spending because it includes some expenditures on industry aid, although the largest portion is for R\&D.

47. Calingaert (1988, p. 87).

48. Speech by Umberto Agnelli, Italian industrialist, to the Royal Institute of International Affairs, London, April 14, 1988. Quoted in Calingaert (1988, p. 93). 
One response to Community preference is for a non-Community firm to establish a joint venture with a Community firm, thus obscuring national origins. For example, Honda has agreed with the U.K. Rover group to produce Honda and Rover models in a jointly owned and managed plant. ${ }^{49}$ Similarly, the AT\&T manufacturing arm has joined with the Dutch company Philips to produce telecommunications equipment for the European market. Such joint ventures may become an important way of creating operations without nationality.

\section{Merger Regulation in the Integrated European Market}

The single integrated market should increase mergers and acquisitions since this is often the least costly way for firms to realize economies of scale. Larger markets are one explanation for the increase in mergers in Europe. The number of mergers, takeovers, and majority shareholding acquisitions involving large firms increased from 117 in 1982-83 to 226 in 1985-86..$^{50}$ There have been similar increases in the acquisition of minority shareholdings and the creation of subsidiaries by large firms. However, given that the eighties were characterized by a worldwide merger wave, it is difficult to establish the particular impact of the coming of 1992.

The recent pattern has been predominantly one of national mergersthat is, the merger of two British or German companies. Such mergers accounted for 50 percent of the total in 1982-83 and 64 percent in 198586. Community mergers, those between two firms in different member states, and international mergers, those between a company inside the Community and one outside, increased in absolute terms but fell proportionately. Community mergers declined from 33 percent of the total in $1982-83$ to 23 percent in 1985-86; international mergers, from 17 percent to 13 percent. ${ }^{51}$

In realizing economies of scale, a national merger serves as well as a Community one, but a Community merger fits better the vision of Europe-wide companies serving markets throughout the Community.

49. "Honda Raises Its Stake in Europe," New York Times, July 14, 1989, p. D1.

50. Emerson (1988, p. 176).

51. Ibid. 
As the report stated, of existing barriers to cross-border mergers, the biggest, "both in terms of launching a cross-border activity and in terms of the administration and location of that activity, is believed to be differences in company law and tax systems." ${ }_{52}$ One task of Europe 1992 is to reduce or eliminate these barriers.

The Community now has limited powers to regulate mergers so that a merger, say between British and German companies, is subject to veto by either the German or British authorities charged in each country with the regulation of mergers as part of national competitive policy. The Commission has for some time urged the adoption of a Community system of notification and control of mergers likely to reduce competition. ${ }^{53}$ The member states have resisted giving the Commission such powers, preferring instead to rely on their own national regulations. The U.S. government has expressed concern over the Commission's merger proposals, fearing that they would be used to give preference to Community mergers over those between U.S. and European firms.

Europe 1992 is likely to increase the pace of merger activity. It is also likely to increase joint ventures, particularly between American and Community firms. But with the larger market of Europe 1992, only exceptional mergers in already highly concentrated industries will be likely to threaten competition. This is so despite the fact that the concentration faced by Europe as a whole is likely to increase, as indeed it already is. The share of the largest $\mathbf{4 0 0}$ firms in manufacturing sales increased from 34 percent to 37 percent from 1978 to $1982 .{ }^{54}$ But the size of the market will be expanding greatly, and the effect of concentration on competition depends largely on firm size relative to a clearly defined market. Throughout, the report stressed increased competition as the source of major gains from Europe 1992, and in that the report was surely correct.

\section{A Concluding Comment}

In my view, the Cecchini report overstates the microeconomic gains of Europe 1992. It will never be established whether I am right or wrong,

52. Ibid., p. 175.

53. Ibid., p. 163-64. The Commission does have power under Article 86 of the Treaty of Rome to act against a merger as an action that creates a dominant position. Such an 
for the estimates are not predictions. They are estimates of long-run gains assuming that certain actions are taken, and it seems unlikely that the complete set of these policy actions will be implemented. No precise date was assigned as to when the gains will be realized, so that a wager on the accuracy of the estimates would never come due. Further, the estimates assume no dramatic changes in the world economy as the single market is created, and yet surely in the intervening years changes will make the estimates moot.

These strictures may not matter. The central points of the Cecchini report are correct. Creating a single integrated market for the 12 member nations will raise real incomes. It will result in at least some reorganization of European industry to realize economies of scale and in increased competition in many European industries.

The obstacles to realizing the microeconomic gains of Europe 1992 are primarily political, a problem the report assumes away. Nations must resist their historic tendency to protect national firms. The past record is only moderately encouraging, for the history of the Common Market's effort to overcome nationalism is marked by two steps forward and one step back.

The entire point of Europe 1992, however, is that nations are to give up their old ways. They are to be committed to making most of Europe one economy. The degree of enthusiasm, indeed even fervor, for Europe 1992 is remarkable. There is a chance, just a chance, that it will make a difference.

action, however, is limited, and hence the Commission has sought a provision similar to Section 7 of the Clayton Act. Swann (1984, p. 138).

54. Emerson (1988, table 8.2.6). 